\title{
Applications of Natural Coagulants to Treat Wastewater - A Review
}

\author{
Vicky Kumar $^{1}$, Norzila Othman ${ }^{2, *}$, and Syazwani Asharuddin ${ }^{1}$ \\ ${ }^{1}$ Department of Water and Environment, Faculty of Civil and Environmental Engineering, \\ UniversitiTun Hussein Onn Malaysia, 86400 Parit Raja, BatuPahat, Johor, Malaysia \\ ${ }^{2}$ Micro-Pollutant Research Centre (MPRC), Faculty of Civil and Environmental Engineering, \\ University Tun Hussein Onn Malaysia, 86400, Parit Raja, Johor, Malaysia
}

\begin{abstract}
The natural water falls from the mountain is merging into the oceans. This water is preserved by humans that are consumed for agriculture, industrial, and municipal use. This water become wastewater after different usage, and finally, completes the hydrological cycle. The water becomes wastewater due to population growth, urbanization, industrialization, sewage from household, institutions, hospitals, industries and etc. Wastewater can be destructive for the public because it contains a variety of organic and inorganic substances, biological substances, toxic inorganic compounds and the presence of toxic materials. The coagulant chemicals and its associated products are resourceful but these may change the characteristics of water in terms of physical and chemical characteristics, this make matters worse in the disposal of sludge. An option of natural polymer can be used in water and wastewater in this review. The natural polymers are most efficient that provide several benefits such as; prolific, exempt from physical and chemical changes from the treated water.
\end{abstract}

\section{Introduction}

Water is a key substance in all natural and human activities. It regenerates the shape of oceans, seas, rivers, lakes and forests, becoming part of hydrological cycle that is important for the development of ecosystems and human life [1]. However since water have been considered as basic need of life, current misuse of water coupled with growing population size, industrialization, change in climate, and urbanization has increased the shrink in cleaning the water reserves [2]. The need for clean water had trigged more comprehensive research in water and wastewater. Heavy metals released into environment that is active in development and rapid growth of industrialization that affect bionetwork. Industries such as; metal coating, excavation, and battery production, consequence of profound metals to ecosystem [3]. It has been discussed that in the developing countries more than 1.6 million people are using the unhygienic water $\&$ among them most of the people suffers from diarrhoea and other water related diseases [4].

*Corresponding author: norzila@uthm.edu.my 
It is described that developing countries are paying a high cost for water treatment by importing the chemicals [5]. There are several methods are utilized to treat the water, depends on the quality of the wastewater. Wastewater is the large seasonal variation that is associated with problems like turbidity, due to solubilize matter and results to more compactable treatment [6]. The physical, chemical, and biological characteristics can be altered by dissolving impurities, which is comprised of organic compounds, gases, minerals and E-coli these effect can be controlled by the concentration and composition of chemical reactions among pollutants [7].

The proper treatment of wastewater resulted to accept that of effluents discharged. Once the effluents enters in environment such river it may health effect such as eye infections, skin diseases, as well as worm infections by hygienic practice that can result the major improvements in health conditions [8]. These effect may be due to pollutant namely suspended solids \& turbidity of the wastewater by using coagulation-flocculation.

Wastewater treatment techniques that are widely used are chemical precipitation, lime coagulation, ion exchange, reverse osmosis and solvent extraction [9].Coagulants are used that added to the water to withdraw the forces that stabilizes the colloidal particles and causing the particles to suspend in the water [10]. Once the coagulant is introduced in the water, the individual colloids must aggregate and grow bigger so that the impurities can be settled down at the bottom of the beaker and separated from the water suspension (as shown in table 1). Various types of coagulants show potential application in treating water and wastewater. It ranges from chemical to non-chemical coagulant. The coagulant also could be synthetic material or natural coagulant with the properties of coagulant having $+v e$ charge, these positive charge proteins would bind to the -ve charged particles in the solution that cause turbidity. water and wastewater treatment is the removal of suspended and colloidal particles, untreated matter, microbes and other substances that are deleterious to life, in search of lowest cost deployment, operation, maintenance, and reduced environmental impacts to the contiguous [11]. Coagulants are characterised according to the wastewater properties that relates to enhance the efficiency of treatment process to achieve required quality of water on standards (as shown in Table 1).Coagulants normally in form of natural (as shown is Table 2) \& synthetic (as in Table 3). Both coagulants aim to remove pollutant in form of physical (solids \& turbidity) or chemical (BOD \& COD). The coagulants also present with advantages various among them.

Table 1. Factors Affecting Coagulation

\begin{tabular}{|c|c|c|}
\hline Coagulant Applications & Effective Characteristics & Natural Water Properties \\
\hline Coagulants Extraction & Settling time & $\mathrm{pH}$ \\
Coagulants Solubility & Turbulence & Alkalinity \\
Coagulants Dosage & 1. Rapid Mixing & Availability of Bacteria's \\
Charge on Particles & 2. Slow Mixing \\
Basicity of a coagulant & Coagulant adds quantity & Presence of Elements (Cl, Na, Mn, \\
& Particles type & Fl, NH3, Fe) \\
& & Total dissolved solids \\
& & Suspended Solids \\
& & Temperature \\
& & Turbidity \\
& & Dissolved Oxygen \\
\hline
\end{tabular}

The impact of $\mathrm{pH}$ and coagulant doses on the coagulation procedure was contemplated in order to streamline comparing to the best evacuation of turbidity. The optimum dosage of $\mathrm{pH}$ will lead to the optimum conditions of JAR test.Coagulation affects the performance of 
the other stages of the treatment, favouring microbiological quality of the final product increasing the lifetime of filters and reducing the final cost of the treated water [11]. Coupled coagulation, flocculation step constitutes conditions of time and agitation where the particles from colliding and coagulating destabilized by forming flakes could be eliminated by sedimentation.

Table 2. Natural coagulants Efficiency

\begin{tabular}{|c|c|c|}
\hline \multirow{2}{*}{ Natural Coagulants } & Turbidity & COD \\
\hline CicerAretinum & $81.20 \%$ & $90.00 \%$ \\
\hline Moringa Oleifera & $82.02 \%$ & $83.33 \%$ \\
\hline Cactus & $78.54 \%$ & $80.65 \%$ \\
\hline
\end{tabular}

Table 3.Synthetic/Inorganic Coagulants Advantages and Disadvantages

\begin{tabular}{|c|c|c|}
\hline Name & Advantages & Disadvantages \\
\hline $\begin{array}{l}\begin{array}{c}\text { Aluminiumsulphate } \\
\text { (Alum) }\end{array} \\
\mathrm{Al}_{2}\left(\mathrm{SO}_{4}\right)_{3} \cdot{ }_{18} \mathrm{H}_{2} \mathrm{O}\end{array}$ & $\begin{array}{l}\text { Easy to handle and apply; most } \\
\text { commonly used; produces less } \\
\text { sludge than lime; most effective } \\
\text { between pH } 6.5 \text { and } 7.5\end{array}$ & $\begin{array}{l}\text { Adds dissolved solids (salts) to } \\
\text { waster; effective over a limited } \\
\text { pH range. }\end{array}$ \\
\hline $\begin{array}{l}\text { Sodium Aluminate } \\
\qquad \mathrm{Na}_{2} \mathrm{Al}_{2} \mathrm{O}_{4}\end{array}$ & $\begin{array}{l}\text { Effective in hard waters; small } \\
\text { dosage usually needed }\end{array}$ & $\begin{array}{l}\text { Often used with alum; high } \\
\text { cost; ineffective in soft waters }\end{array}$ \\
\hline $\begin{array}{l}\text { Polyaluminium Chloride } \\
\text { (PAC) } \\
\mathrm{Al}_{13}(\mathrm{OH})_{20}(\mathrm{SO})_{4} \cdot \mathrm{Cl}_{15} \\
\end{array}$ & $\begin{array}{l}\text { In some applications, Floc, } \\
\text { formed is more dense and faster } \\
\text { settling than alum }\end{array}$ & $\begin{array}{l}\text { Not commonly used; little full } \\
\text { scale data compared to other } \\
\text { aluminium derivatives }\end{array}$ \\
\hline $\begin{array}{c}\text { Ferric Sulfate } \\
\mathrm{Fe}_{2}\left(\mathrm{SO}_{4}\right)_{3}\end{array}$ & $\begin{array}{l}\text { Effective between } \mathrm{pH} 4-6 \text { and } \\
8.8-9.2\end{array}$ & $\begin{array}{l}\text { Ads dissolved solids(salts) to } \\
\text { water; usually need to add } \\
\text { alkalinity }\end{array}$ \\
\hline $\begin{array}{l}\text { Ferric Chloride } \\
\mathrm{FeCl}_{3} \cdot 6 \mathrm{H}_{2} \mathrm{O}\end{array}$ & Effective between $\mathrm{pH} 4$ and 11 & $\begin{array}{l}\text { Adds dissolved solids (salts) to } \\
\text { water; consumes twice as much } \\
\text { alkalinity as alum }\end{array}$ \\
\hline $\begin{array}{l}\text { Ferrous Sufate } \\
\text { (Copperas) } \\
\mathrm{FeSO}_{4} \cdot 7 \mathrm{H}_{2} \mathrm{O}\end{array}$ & Not as $\mathrm{pH}$ sensitive as lime & $\begin{array}{l}\text { Ads dissolved solids(salts) to } \\
\text { water; usually need to add } \\
\text { alkalinity }\end{array}$ \\
\hline $\begin{array}{c}\text { Lime } \\
\mathrm{Ca}(\mathrm{OH})_{2}\end{array}$ & $\begin{array}{c}\text { Commonly used; very } \\
\text { effective; may not add salts to } \\
\text { effluent }\end{array}$ & $\begin{array}{c}\text { pH dependent; produces large } \\
\text { quantities of sludge; overdose } \\
\text { can result in poor effluent } \\
\text { quality } \\
\end{array}$ \\
\hline
\end{tabular}

\section{Applications of natural coagulants to treat wastewater}

The natural coagulants are used in wastewater treatments include microbial polysaccharides, starches, gelatin galactomannans, cellulose derivatives, chitosan, glues, and alginate. Coagulants which carry natural characteristics supposed to be harmless for human health, whereas existence of aluminium zest may provoke neurology \& pathology diseases [11]. Natural coagulants are mixed with some artificial coagulants that are consumed as coagulant aid, their effectiveness as the key coagulant remains stays at early stages. The process of treatment in these coagulants composed of molecules bridging, adsorption, and charge balancing. Natural coagulants are capable for wastewater treatment following effluents discharge standard. 


\section{Non-plant-based coagulants}

Polymeric coagulants preserve cationic, anionic, or non-ionic, in which sometimes two are communally described as polyelectrolytes. Generally, the polymers used in wastewater treatment are artificial, the natural polyelectrolyte is persistent. Previous studies regarding natural coagulants is taking place among those are referred as 'polyelectrolytes' although many of these studies did not essentially carry out in-depth to determine chemical characterization and their ionic activity. Naturally, coagulants are polysaccharides or proteins. Polymers categorized as non-ionic due to lack of charged interactions, there may be interactions among partially charged groups of the polymer and a solvent within a solution may contain including $-\mathrm{OH}$ along its chain [12]. Chitosan is a natural polysaccharide with many useful lineaments such as; hydrophilicity, biocompatibility, and the capability of adsorbing number of metal ions because of its amino groups. Chitosan is an example cellulose-like biopolymer generally distributed in nature, mainly in marine invertebrates, insects, yeasts, and fungi.

Chitosan is the acetyl group and derivative of chitin, a natural polysaccharide found primarily in the arthropods and some fungi. Chitosan contains behaviour like non-toxic, biodegradable, linear cationic polymer of high molecular weight. Moreover, chitin extraction does not cause any flap to the ecosystem, it gains all advantages provided by polysaccharides, in vision of it as the source of chitosan [13].

Alginates are plentiful in nature, having both capsular polysaccharides in soil bacteria and structural component in aquatic brown algae (phaeophyceae) that encompass up to $40 \%$ of dry matter. Alginates are linked to their ability to keep water viscosifying, their gelling, and stabilizing properties. Alginates is the simply polysaccharide, it naturally contains carboxyl groups and various abilities for functional materials.

Components of actinobacteria contain infinite sources of new compound and hold an essential arrangement due to their variety and proved ability to create new bioactive compound [14]. Oladoja in [15] gives comprehensive review of research summary involving actinobacteria coagulants. The research of biocoagulating activity using Cellulomonas and Streptomyces species were evaluated individually in synthetic turbid water of kaolin suspension showed significant flocculating activity [16]. The chemical analyses revealed that the presence of polysaccharides and protein with neutral sugar, amino sugar and uranic acids which might contributing to its high flocculating activity.

\section{Plant-based coagulants (PBC)}

The PBC are broadly utilized for the purification of contaminated water that is in less urbanized, because they seems to be less carrying cost treated coagulates as compared to artificial. PBC coagulants are assumed to treat water showing low-to-medium turbidity range (50-500) NTU. It is unforeseen that a complete decisive analysis of existing PBC is still imaginary in this 21 st century. The significance of PBC to ecosystem in the end yield to an instant area for researcher in strengthening the investigation to find inherent resources [17]. Among PCB described namely, Nirmali seeds, Moringa oleifera, Tannin and Cactus.

Anionic polyelectrolytes are polymers of nirmalii seed whose particles get faded in water by through inter particle bridging. The seed extracts contains $-\mathrm{COOH}$ and $-\mathrm{OH}$ groups that are able increase the coagulation competency because lipids, carbohydrates and alkaloids. Galactomannani and galactanii are mixture of polysaccharide division that are extracted from Strychnospotatorum seeds which is capable in reducing turbidity up to $80 \%$. In all aspects, the galactomannans are prepared up 1,4-linked $\beta$-d-mannopyranosyli residuum mien end $\alpha$-d-galactopyranosyl units associated with $0-6$ point of some manner residue. Nirmali seeds and its associated coagulation process yet not been studied,[18] the 
presence of abundant amount of $-\mathrm{OH}$ groups along chains of galactomannan and galactan provides weakly but profuse adsorption that eventually lead to the preceding coagulant interparticle bridging effect more research can be carried out in this aspects [18].

Moringa oleifera, is a non-hazardous (low concentrated) stifling plant whose seeds contain an edible oil and water soluble substance. It is widely known that this plant can be utilized for beneficial purposes. Moringa is most often consuming as provisions and remedial resource limited to urban areas [19]. The most recommended coagulating agents with $12-14 \mathrm{kDa}$ mass and about 10-11 isoelectric point $(\mathrm{pI})$ are dimeric cationic proteins. Adsorption and charge neutralization its main coagulation method. Cationic protein having pI greater than 9.6 and mass, no less than $6.5 \mathrm{kDa}$. Conversely, Okuda argue that active elements from an aqueous extraction of salt that is not a polysaccharide or protein, actually they are organic polyelectrolyte having molecular mass of 3.0kDA [20]. It is also discussed that bivalent cations are highly regarded (e.g. $\mathrm{Ca} 2+$ and $\mathrm{Mg} 2+$ ) that raise the effect of moringa oleifera.

It is known that interface provides strong adsorption in system, it also neutralized particles that may occur charge problem [21]. Accumulation of cations can enhance the coagulant competency. Natural materials that are achieve from polyphenolic substructure are commonly known as tannin, such as Acacia, Castanea, or Schinopsis extracted from bark and wood. Applications of tannin are widely studies to treat water containing nitrogen atom with a lone pair and carbolic acid groups. Tannin gives $3 \mathrm{meq} / \mathrm{g}$ charge density, since cationic in environment there is a single tertiary amine group per monomer [22]. Tannis molecular weight ranges from 100 to 10,000 that is generally tanning agent in lather industry. However, such studies still can be explored in future [23]. Furthermore, it also defines that tannin is impartial coagulant as aid that can be used to treat the water and wastewater treatment. It is general comprehension phenolic groups stabilized via resonance. This gives attention that tannin structure is capable for coagulation.

Most known cactus genus treating water 'nopal' in Mexico and 'prickly pear' in North America. This type of cactus is related with nutritional food sources \& remedial characteristics. Beside opuntia cactus latifaria is widely used natural coagulant. The opuntia high coagulation ability recognized to the presence of mucilage assumes as complex carbohydrate and sticky, storage of these compounds in internal cactus and surface pads has high water retention capability. Mucilage in cactus opuntia has fiber such as 1-rhamanosei, 1-arabinose, d-galactose, d-xyloose, and galacturonic acid, predominantly during a bridging coagulation method solution particulates carry out indirectly contact from the cactus genus [24]. The most capable coagulation and active element is galacturonic acid, it is wellknown $50 \%$ of turbidity removal [25].

Another option of plant based coagulant using unexploded waste such as cassava peel. Fresh cassava peels have three main efficiencies: spread very rapidly, contain phytates, and huge amounts of cyanogenic glycosides. To shrink cyanogenic \& phytate substance to maintain their natural value, altered methods are adopted in sinking cyanogenic glycoside like sun-drying, ensiling, and soaking + sun-drying. Peels are chopped to obtain good quality $2 \mathrm{~cm}$ for easy compression, and sagging for two days to decrease moisture substance from $70-75 \%$ to about $40 \%$ [25]. After 21 days cassava peel silage was observe as light brown in appearance, with satisfying odour. The $\mathrm{pH}$ recorded as 4.4 , and fungal growth was negligible.

\section{Mechanism of coagulation by natural coagulants}

The mechanism of coagulation established an idea that there may be interaction between the polymer and the dissolved particles in a solution due to the fact that natural polymer contain numerous charged functional groups residing in their polysaccharide chain such as 
$-\mathrm{OH},-\mathrm{COOH}$, and $-\mathrm{NH}$. In general processing coagulant involves four steps, such as bridging mechanisms, charge neutralization, double layer compression, and sweep-floc mechanism [26]. Natural coagulants are commonly composed of the combination of several macromolecules such as carbohydrates, protein and lipids. In many cases, the major building blocks are the polymer of polysaccharides and amino acids [27].

In many practical cases, cationic polyelectrolytes are the most promising flocculants to undermine contaminated particles that are -ve charged. Electrostatic interaction provides strong adsorptions that neutralize the particles surface and potentially cause charge reversal. Moreover, flocculation may take place due to the reduction of particles surface charge and decreased electrical repulsion between them [21]. Many studies carried out on polyelectrolyte of maximum charge density is efficient simply as, at a given dosage, they have good ability to deliver further charge to the particle shell. Moreover, when maximum charge density polyelectrolyte absorbed on -ve surfaces with a fairly less density of potential sites, another prospect arises called 'electrostatic patch mechanism' [21]. The adsorbed polyelectrolyte chains thus type of charge alternating positive and negative charges which give particle attraction and hence flocculation occurred. Coagulating agents in moringa oleifera are cationic proteins with molecular mass of $12-14 \mathrm{kDa}$ and iso-electric point $(\mathrm{Pi})$ lies under $10-11$. The researchers also conclude that the main mechanisms that govern the coagulation activity are adsorption and charge neutralization.

The bridging mechanism has been recognized by many studies using various coagulants like moringa oleifera remove, sago starch and cassia seed gum. Long chain polymers absorbed on particles can have head and tails entering several techniques into the solution. For a bridging mechanism, it is necessary to have much space that can attach divisions of polymer chains to engross other particles. Therefore, importance of most favourable amount for bridging mechanism is suitable [21]. Previous study has follow that the microbe extract of Nirmali contain carbohydrate, lipids, and alkaloids having $-\mathrm{COOH}$ and $-\mathrm{OH}$ groups which enhance its coagulating potential. Polysaccharide particles extracts from Nirmali seed contained galactomannan and galactan which is competent in turbidity removal up to $80 \%$ of kaolin solution. Abundant adsorption sites of $-\mathrm{OH}$ beside the chains of galactomannan and galactan that constituted in nirmali seed extracts lead to inter particle bridging effect.

Generally, sweep flocculation gives significantly particle elimination than just particle destabilization like in charge neutralization mechanism due to superior rate of aggregation as the result of increased solids concentration. Sweep flocculation is used to trap suspended solids that are harmful for the mesh composition [28]. Same mechanism was proposed, on the treatment of turbid water by chitosan. The study showed that sweeping mechanism dominates the kaolinites removal when the $\mathrm{pH}$ in the range of 7.0 to 8.5 [29].

\section{Processing Steps of Natural Coagulants}

The first processing phase is widely and essentials for conjugal application for utilization. In this step plant is being cut, sliced, chop and peel for drying purpose by manual or mechanical pulverization to avoid undesired parts. Conventional method involves aeration and following pulp of plant parts into particles are then used by local area due to lack of such equipment. In the second processing phase, organic and/or alcoholic solvents extraction is used to remove the active agents. However, water\&salt solution $(\mathrm{NaCl})$ extraction [30] also used. The previous research pointed out that by using $\mathrm{NaCl}$ solution extraction with lower dosages as 7.4 times higher to eliminate kaolinite turbidity. The author also endorsed improved the substance in proteins whereas substance increases protein anion and ability of solution. Third process phase involves dialysis, lyophilization, ion-exchange and precipitation to treat water as viable refining methods forMoringa 
oleiferastepped for treatment of higher volume of turbid water [31]. Such methods are not much actively used over other PBCs; therefore it shows opportunity for researcher to explore this area.

\section{Conclusion}

Natural coagulants are obtained from several natural sources, when functional as coagulants primary or auxiliary coagulation/flocculation present as feasible and economical alternatives. There are two types of coagulants are found natural and synthetic. Function of coagulants in wastewater treatment is to remove various parameters. Coagulants are present in twoform, first is plant based coagulants (PBC) and second is non-plant based coagulants. The preparation of natural coagulants is consisting over three steps for the substitution of the dosage of the coagulant in treating wastewater.The treatment through bio coagulants signifies to a vital development in viable environment for better worth of eco-system particularly for less urbanised area. An attempt is using eco-friendly coagulant as a natural coagulant for the process of coagulation to treat wastewater. New coagulant processing technique such as composite polymerization and impregnation method can be incorporated in producing coagulants with enhanced capability. This review highlighted that many potential advantages in using natural coagulants from various sources of plants, animal or biomass.

This research was supported by UniversitiTun Hussein Onn Malaysia (UTHM), Malaysia, The Ministry of Higher Education Malaysia through Fundamental Research Grant Scheme (FRGS), Vot. 1575.

\section{References}

[1] J.D.P Theodoro, G.F Lenz, R.F Zara, R. Bergamasco, Coagulants and Natural Polymers: Perspectives for the Treatment of Water, Plastic and PolymerTechnology (PAPT), 2, 55-62 (2013)

[2] A.D, BENETTI, "Water reuse: issues, technologies, and applications" Sanitary and Environmental Engineering", 13(3), 247-248, (2008)

[3] N.Othman, S.M.Asharuddin, "Cucumismelorind as biosorbent to remove Fe (II) and Mn (II) fromsyntheticgroundwater solution, " In Adv. MaterialsResearch", 795, 266271 (2013)

[4] R. Sowmeyan, J. Santhosh, and R. Latha, Effectiveness of herbs in community water treatment, Int: Research J. of Biochemistry and Bioinformatics, 1, 297-303, (2011)

[5] K.A.Ghebremichael, K. R. Gunaratna, H.Henriksson, H.Brumer, G.Dalhammar,A simple purification and activity assay of the coagulant protein from Moringa oleiferaseed, Water research, 39, 2338-2344 (2005)

[6] G. L.McConnachie, G. K. Folkard, M. A. Mtawali, J. P. Sutherland, Field trials of appropriate hydraulic flocculation processes, Water research, 33,1425-1434 (1999)

[7] A .Sethupathy, An Experimental Investigation Of Alum And Moringa Oleifera Seed In Water Treatment, Int. J. of Adv. Res.,, 3, 515-518 (2015)

[8] K.A Yongabi, "Biocoagulants for water and waste water purification: a review,Int: review of chemical engineering, 2, 444-458 (2010)

[9] R.Azizul, M.F, Mohd-Suhaimi, N.Othman, Biosorption of $\mathrm{Pb}(\mathrm{II})$ and $\mathrm{Zn}$ (II) in Synthetic Waste Water by Watermelon Rind (Citrulluslanatus), AppiedMechanics and Materials, 465, 906-910 (2014) 
[10] A.I. Cissouma, F. Tounkara, M. Nikoo, N. Yang, and X. Xu. Physico-Chemical Properties and Antioxidant Activity of Roselle Seeds Extracts.,Advance J. of Food Science and Technology, 5(11), 1483-1489 (2013)

[11]R.Rajendran, M. Abirami, P. Prabhavathi, P. Premasudha, B. Kanimozhi, A. Manikandan, Biological treatment of drinking water by chitosan based nanocomposites. African J. of Biotechnology,14(11), 930-936 (2015)

[12] M A AHusan, L S Hui, Z.N Zainura, Removal of Boron from Industrial wastewater by chitosan via chemical precipitation, J. Chemistry Nat Res Engineering, 4, 1-11(2009)

[13]A. Montembaulti, V.Christophe, and D.Alain., Biomaterials, Physico-chemical studies of the gelation of chitosan in a hydro alcoholic medium, Biomaterials, 26, 933-943 (2005)

[14]M.E Mabrouk, Production of bioflocculant by the marine actinomycete Nocardiopsisaegyptia sp. Nov, life sciences J. 11, 27-35 (2014)

[15]N.A. Oladoja, Headway on natural polymeric coagulants in water and wastewater treatment operations, J. of Water Process Engineering, 6, 174-192 (2015)

[16]U.U Nwodo, G. Ezekiel, V. Leonard, K.O, Mabinya, K.Rumbold, C.O.Lawrence, I.Anthony, Bioflocculant production by a consortium of Streptomyces and Cellulomonas species and media optimization via surface response model.Colloids and Surfaces B: Biointerfaces, 116, 257-264 (2014)

[17]M.J. Pearse, Historical use and future development of chemicals for solid-liquid separation in the mineral processing industry., Mineral Engineering, 16(2), 103-108 (2003)

[18]C.Y.Yin, Emerging usage of plant-based coagulants for water and wastewater treatment.Process Biochemistry, 45(9), 1437-1444 (2009)

[19]F.Anwar, S Nahid Zafar, and Umer Rashid, Characterization of Moringa oleifera seed oil from drought and irrigated regions of Punjab, Pakistan. Grasas Y Aceites, 57(2), $160-168$ (2006)

[20] Okuda, Tetsuji, U.B. Aloysius, N. Wataru, O.Mitsumasa, Isolation and characterization of coagulant extracted from Moringa oleifera seed by salt solution. Water research, 35(2), 405-410 (2001)

[21]B.Bolto, J.Gregory, Organic polyelectrolytes in water treatment." Water research, 41(11), 2301-2324 (2007)

[22] ÖZACAR, MAHMUT, I.A.ŞENGILL, The use of tannins from turkish acorns (valonia) in water treatment as a coagulant and coagulant aid,Turkish J. of Engineering and Environmental Sciences, 26(3), 255-264 (2002)

[23] Graham, Nigel, F.Gang, G.Fowler, M.Watts, Characterisation and coagulation performance of a tannin-based cationic polymer: A preliminary assessment. Colloids and surfaces A: Physicochemical and engineering aspects, 327(1), 9-16 (2008)

[24]C.Saenz, E. Sepúlveda, B.Matsuhiro, Opuntia spp mucilage's: a functional component with industrial perspectives. J. of Arid Environments, 57(3), 275-290 (2004)

[25]S.M.Miller, E.J.Fugate, V.O.Craver, J.A.Smith, J.B.Zimmerman, Toward understanding the efficacy and mechanism of Opuntia spp. as a natural coagulant for potential application in water treatment. Environmental science \& technology, 42(12), 4274-4279 (2008)

[26]Renault, Francois, B.Sancey, P-M.Badot, G.Crini, Chitosan for coagulation /flocculation processes-an eco-friendly approach. European Polymer J., 45(5), 13371348. (2009) 
[27]M.Adinolfi. M.M.Corsaro, R.Lanzetta, M.Parrilli, G.Folkard,W.Grant, J.Sutherland, Composition of the coagulant polysaccharide fraction from Strychnospotatorum seeds. Carbohydrate research, 263(1) 103-110 (1994)

[28] M.B. Sciban, M.T.Klasnja, J.Lj.Stojimirovic. Investigation of coagulation activity of natural coagulants from seeds of different leguminose species. Acta PeriodicaTechnologica (Serbia and Montenegro) APTEFF, 36, 1-266 (2005)

[29]B. Bina, M. Mehdinejad, M. Nikaeen, H.M. Attar, Effectiveness of chitosan as natural coagulant aid in treating turbid waters. J. of Environmental Health Science \& Engineering, 6(4), 247-252 (2009)

[30] Adamafio, N. Ayikailey, M. Sakyiamah, J. Tettey, Fermentation in cassava (ManihotesculentaCrantz) pulp juice improves nutritive value of cassava peel. African J. of Biochemistry Research, 4 (3), 51-56 (2010)

[31]B. Lukuyu, I.Okikie, A.J Duncan, M. Beveridge, M.Blummel, Use of cassava in livestock and aquaculture feeding programs. Int. Laboratory for Research on Animal Di, 25, 1-83 (2014) 